J. Lake Sci. (湖泊科学), 2016, 28(2): 350-357

DOI 10. 18307/2016. 0215

(c) 2016 by Journal of Lake Sciences

\title{
太湖缓冲带林下草坪的生长趋势研究”
}

\author{
刘长娥 ${ }^{1,2}$,邹国燕 ${ }^{1,2 * *}$, 周 胜 ${ }^{1,2}$, 付子轼 ${ }^{1,2}$, 陈桂发 ${ }^{1,2}$ \\ (1: 上海市农业科学院生态环境保护研究所, 上海 201403) \\ (2: 上海低碳农业工程技术研究中心, 上海 201415)
}

\begin{abstract}
摘 要: 为提升太湖缓冲带林带的生态功能, 减少人湖污染负荷, 采用人工草坪替代林下杂草的方式, 建立林草复合带. 选取白三叶 (Trifolium repens)、红花酭浆草 (Oxalis corymbosa)、麦冬 (Ophiopogon japonicus)、马蹄金 (Dichondra erpens) 和狗 牙根 (Cynodon dactylon) 5 种草坪, 在典型缓冲带林地按间距 $25 \mathrm{~cm}$ 统一移栽种植. 采用定位监测的方法分析草坪的生长 特征与发展趋势. 结果表明: 2011-2014 年期间, 除狗牙根无法形成稳定的种群被杂草取代外, 其他 4 种草坪均能正常 生长, 并形成优势种群; 4 种草坪中, 以麦冬和马蹄金生长状况最好, 生物量、盖度、均一性和青绿期综合指标等级较高, 其次是白三叶;红花酢浆草种群不稳定, 受水热的影响大.
\end{abstract}

关键词: 草坪;生长趋势; 缓冲带; 林下;太湖

\section{Growth trend of lawns under the forest in buffer zone of Lake Taihu}

\author{
LIU Chang'e ${ }^{1,2}$, ZOU Guoyan ${ }^{1,2 * *}$, ZHOU Sheng ${ }^{1,2}$, FU Zishi ${ }^{1,2}$ \& CHEN Guifa ${ }^{1,2}$ \\ (1: Eco-environmental Protection Institute, Shanghai Academy of Agricultural Sciences, Shanghai 201403, P.R.China) \\ (2: Shanghai Engineering Research Centre of Low-carbon Agriculture (SERCLA), Shanghai 201415, P.R.China)
}

\begin{abstract}
In order to promote the ecology function of forest in buffer zone of Lake Taihu and decrease the pollution load of inflows the lake, forest-grass composite strips were established by substituting undergrowth weeds with artificial lawns. The growth feature and trend of five kinds of lawns, Trifolium repens, Oxalis corymbosa, Ophiopogon japonicus, Dichondra erpens and Cynodon dactylon planted in $25 \mathrm{~cm}$ under the forest in buffer zone were studied by positioning monitoring in this paper. The results are as follows : During $2011-2014$, the most types of lawns could grow normally and formed a dominant population, except for Cynodon dactylon replaced by the weeds; Ophiopogon japonicus and Dichondra erpens were the best in terms of biomass, coverage, uniformity and green period, followed by the Trifolium repens, while Oxalis corymbosa population were unstable which affected by the hydrothermal conditions.
\end{abstract}

Keywords: Lawn; growth trend; buffer zones; under forest; Lake Taihu

草坪作为一种地被植物, 是重要的绿化措施, 除能给人们提供优美的环境以及休闲娱乐场所外, 还具有 巨大的生态、环境功能, 草坪在城镇环境绿化中扮演着十分重要的角色. 随着草坪建设功能化和多样化的 发展, 将草坪推广利用至缓冲带, 充分发挥其径流拦截作用, 减轻径流携带养分对湖泊水体的污染将是一个 新的发展趋势.

太湖流域是我国水体富营养化最严重的地区之一, 而农田氮 $(\mathrm{N})$ 、磷 $(\mathrm{P})$ 流失是该流域水体富营养化的 重要影响因素 ${ }^{[1-2]}$, 究其原因, 与缓冲带植物种植模式和施肥方式等因素有关.太湖缓冲带农田主要种植蔬 菜、水稻、豆类等经济作物, 施肥多采用随机播撒 (如化肥) 或覆盖于地表 (如鸭粪) 等方式, 在降雨的冲刷下 肥料大量外泄, 形成较大的污染源. 而处于农田下游的防护林, 林下自然生长着杂草, 同时兼有攀援植物缠 绕, 严重影响了林木的健康生长, 削弱林带的主体生态功能. 另外, 由于杂草世代更替, 产生大量的调落废

* 国家水体污染控制与治理科技重大专项 (2012ZX07101-009) 资助. 2015-04-02 收稿;2015-08-21 收修改稿. 刘 长娥( $1967 \sim)$, 女, 博士, 副研究员; E-mail: le566@163.com.

** 通信作者;E-mail: zouguoyan@263. net. 
弃物 ${ }^{[3]}$, 日积月累, 腐烂落叶释放的营养盐会随降雨径流进人湖泊, 进一步增加了水体的污染负荷, 严重威 胁着湖泊的生态安全. 相对于高大杂草, 常绿低矮草坪, 不仅能够减少防护林系统内部污染物的产生, 而且 其低矮致密的生长特点可以减少水土流失, 林草结合可以有效拦截上游农田流失的 $\mathrm{N} 、 \mathrm{P}$, 较大程度地将 $\mathrm{N}$ 、 $\mathrm{P}$ 保留在陆地生态系统物质循环之中, 对减缓太湖水体的富营养化进程, 减轻太湖污染负荷具有重要意义.

以往草坪主要种植于城镇绿地及公园中, 其生长环境和管护条件较好, 草坪的生长受不利环境的影响 较小. 而缓冲带防护林下不仅光热条件较城镇绿地差, 而且由于杂草常年生长, 土壤中积累了大量的种子, 草坪在生长过程中不仅要忍耐不利环境, 同时还要与众多杂草进行竞争, 最终形成优势种群才能立足于防 护林下. 基于这种现状, 在修复缓冲带生态系统和治理修复与其相邻的缓冲区生态功能思想的指导下, 本 研究试图通过选取几种适宜缓冲带林下生长的草坪种类, 建立草带, 形成林草复合带, 提升林带的生态功 能, 增加防护林对湖泊的生态保护作用.

以往对草坪的生长也有研究 ${ }^{[4-8]}$, 但针对缓冲带林下草坪生长的研究鲜有报道, 本研究通过分析不同种 类草坪的生长态势, 了解林下适宜的草坪种类, 有望为缓冲带林草复合带的建置提供科学指导.

\section{1 材料与方法}

\section{1 研究区概况}

研究区位于太湖西岸的周铁地区 $\left(31^{\circ} 21^{\prime} \sim 31^{\circ} 27^{\prime} \mathrm{N}, 119^{\circ} 56^{\prime} \sim 120^{\circ} 01^{\prime} \mathrm{E}\right)$, 属长江三角洲太湖水网化平 原, 沿太湖有长达 $22.3 \mathrm{~km}$ 的湖岸线. 年平均降雨量为 $1210.4 \mathrm{~mm}$, 其中, 春季降雨量占全年的 $29 \%$, 夏季占 $36 \%$, 秋季占 $22.5 \%$, 冬季占 $12.5 \%$. 全年约 $49 \%$ 的雨量集中在 6-9 月, 以 6 月最多. 年平均气温为 $15.6^{\circ} \mathrm{C}$. 受太湖水气的影响, 平时空气湿度较大, 昼夜温差较小.

研究区土壤为夜潮土, 林地树木种类主要是香樟 (Cinnamomum camphora), 另有少量臭椿 (Ailanthus altissima)、楝树( Melia azedarach)。林下原生草被(杂草)有看麦娘(Alopecurus aequali)、早熟禾 (Poa annua)、蒲 公英( Taraxacum mongolicum)、一年蓬(Erigeron annuus)、小飞蓬(Comnyza canadensis)、紫苑 (Aster tataricus)、 大巢菜( Vicia sativa)、野荠菜 (Capsella bursa-pastoris)、大蒜芥 (Sisymbrium altissimum)、野胡萝卜 (Daucus carota)、芫荌(Coriandrum sativum)、猪殊殊(Galium aparine)、牛繁缕(Malachium aquaticum)、通泉草( Mazus japonicus)、葎草 ( Humulus scandens)、老鹳草 (Geranium wilfordii)、杜板归 (Polygonum perfoliatum)、酸模 (Rumex acetosa)，分属禾本科(Gramineae)、菊科(Compositae)、豆科(Leguminosae)、十字花科(Cruciferae)、伞 形科( Umbelliferae)、茜草科( Rubiaceae)、石竹科(Caryophyllaceae)、玄参科 (Scrophulariaceae)、桑科( Moraceae)、陇牛儿苗科(Geraniaceae)、苶科 (Polygonaceae). 共计 12 科 17 属 18 种, $90 \%$ 以上为一年生草本.

\section{2 供试材料}

选取当地常见的草坪种类白三叶 (Trifolium repens)、红花酢浆草 (Oxalis corymbosa)、麦冬 (Ophiopogon japonicus)、马蹄金 (Dichondra erpens) 和狗牙根 (Cynodon dactylon) 作为林下草坪材料.

\section{3 实验设计}

2010 年选取缓冲带典型的防护林地 (面积较大, 处于农田与水体之间), 清除了林下部分杂草, 采用间 距 $25 \mathrm{~cm}$ 将 5 种供试材料移栽种植于林下, 每种草坪处理地块面积相等, 约 $30 \mathrm{~m}^{2}$. 在不同种类草坪中设置 固定样方 $(1 \mathrm{~m} \times 1 \mathrm{~m}), 2$ 个重复, 主要用于定位观测株高. 草坪移栽的第 2 年, 待其成活并正常生长后, 在草 坪生长期内, 根据植物的生长节律, 进行相关指标的测定.

\section{4 测定项目与方法}

主要测定项目有: 草坪的青绿期、均一性、草坪的高度、盖度和生物量. 其中, 青绿期为 $2 / 3$ 植株保持青 绿状态的天数; 均一性主要指草坪密度和整齐度, 均一性好的草坪不同区域之间的密度和整齐度差异较小, 采用目测, 按优、良、中、低、劣进行划分, 其标准以供试草坪中最好的为优, 依次类推; 草坪高度为植株的自 然高度, 在固定样方中每个重复按梅花型布点, 定位选取 5 株测定株高, 2 个重复共计 10 株, 以平均值作为 该种类草坪的高度; 盖度为地上植株垂直投影面积占样地面积的百分比, 用样方框随机选取一定面积, 重复 3 次, 采用目测方法进行估测; 生物量为单位面积植株地上部分的干重, 为保证草坪实验的长期进行, 减少采 样对草坪的损害, 每次测定时在每种草坪的样方外, 利用样方框随机套取 $1 \mathrm{~m} \times 1 \mathrm{~m}$ 样方, 重复 3 次. 对于株 
丛明显的草坪 (麦冬、红花眽浆草) 数出单位面积内的株丛数, 然后随机选取 1 株丛; 对于株丛不明显草坪 (白三叶、马蹄金、狗牙根) 随机选取 $10 \mathrm{~cm} \times 10 \mathrm{~cm}$ 的面积, 分别齐地面刈割, 将地上部分植株装人相应名称 编号的密封袋, 带回实验室, 先在 $105^{\circ} \mathrm{C}$ 烘箱下杀青 $30 \mathrm{~min}$, 然后将烘箱调至 $80^{\circ} \mathrm{C}$ 烘干至恒重, 称取重量, 换 算为单位面积草坪生物量. 在植物生长季, 每 2 月对 5 种草坪的青绿期、均一性、草坪的高度、盖度和生物量 进行 1 次测定, 以了解不同草坪在林下的生长趋势,为缓冲带林下草坪的选取提供依据.

\section{5 数据处理}

采用 Excel 2003 软件制图, 利用 SPSS 12.0 软件中的 One-way ANOVA 分析 5 种供试草坪不同年份以及 相同年份不同时期的株高、生物量、盖度的变化了解各指标随生长时间的变化特征与趋势.

\section{2 结果与分析}

\section{1 不同生长年限生物量特征}

草坪 2010 年移栽种植, 2011 年开始测定至 2014 年,2012 年由于某种原因未测定. 草坪生长的 4 年中,

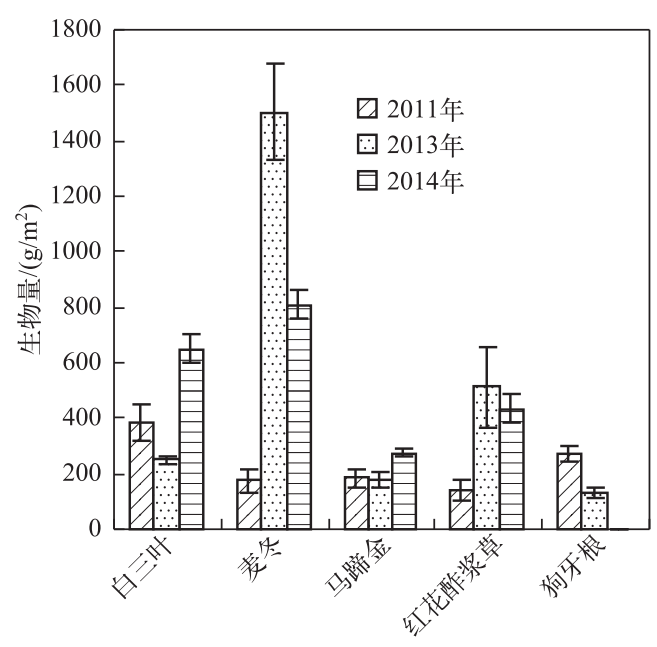

图 1 不同年份草坪最高生物量对比

Fig. 1 Contrast of the highest biomass of lawns in different years 每年的生长都发生变化, 不同年份间生物量的差异除受 水热等自然因素影响外,主要受植物生长特性和耐受性 的影响. 不同植物的分蕃特征与生长高峰期不同, 白三 叶、马蹄金与狗牙根主要通过匍匐茎进行扩展与生长, 生物量的增长受匍匐茎的特征与生长速度影响, 3 种匍 匐型草坪相比, 白三叶的匍匐茎粗大, 侵占性强, 枝叶茂 盛,但易感染白粉病,形成秃斑, 而使生物量受到影响; 马蹄金的匍匐茎柔细,生长缓慢, 因此不同年份生物量 变化较小; 狗牙根的匍匐茎生长较快, 尤其在水热适宜 时期, 前期的老枝条不断被新生枝条覆盖后形成草丘, 导致下部枝条死亡而影响生长, 随时间延长, 生物量逐 渐降低; 红花酢浆草和麦冬是通过萌发新的分菜株进行 种群的扩展, 生物量的高低取决于新株萌发的数量和生 长状况, 2 种草坪在移栽 3 年后, 分藥能力逐渐减弱, 因 此,生物量大幅度降低. 在调查期间, 白三叶和马蹄金 移栽的第 4 年生物量相对较高, 麦冬和红花酢浆草在移 栽的第 3 年生物量较高, 而狗牙根则在移栽的次年生物 量较高 (图 1).

5 种草坪的生长态势不同 (图 2), 草坪移栽后的 4 年内, 白三叶、红花酢浆草和狗牙根个别年份生物量 随生长发育呈现降低趋势, 而麦冬与马蹄金生物量均随生长发育呈不同程度的增长趋势, 在某种程度表明 这 2 种草坪在防护林下具有良好的发展趋势.

白三叶移栽后的前期 (2011 年)生物量快速增长, 随生长发育生物量显著增加; 中期 ( 2013 年) 生长缓 慢, 趋于停止, 主要受白粉病的影响; 后期 (2014 年)生物量随生长时间呈现缓慢增长趋势. 红花酰浆草移栽 后的前期生物量缓慢增长; 中期呈快速增长趋势, 与生长时间呈显著正相关; 后期生长趋于减弱, 生物量随 生长时间呈降低趋势, 但不显著. 麦冬不同年份生物量均呈增长趋势, 尤其是移栽后的前期生物量与生长 时间呈显著正相关.马蹄金移栽后的前期和中期生物量增长趋势基本一致, 与生长时间呈显著正相关; 后 期生物量增长趋于缓慢. 狗牙根移栽后的前期生物量呈快速增长趋势; 移栽的第 3 年生物量开始呈减少趋 势,之后被杂草取代而消失.

5 种草坪移栽于林下 4 年后, 除狗牙根被杂草取代外, 其他 4 种草坪均能正常生长, 并形成优势种群.

\section{2 不同生长年限高度与盖度特征}

不同时期草坪的高度受植物生长、温度、水分等多方面影响, 5 种草坪中, 麦冬草坪高度受各种因素的影 响大, 不同生长期以及不同年份高度不稳定, 出现波动.马蹄金、狗牙根草坪矮, 高度比较稳定. 

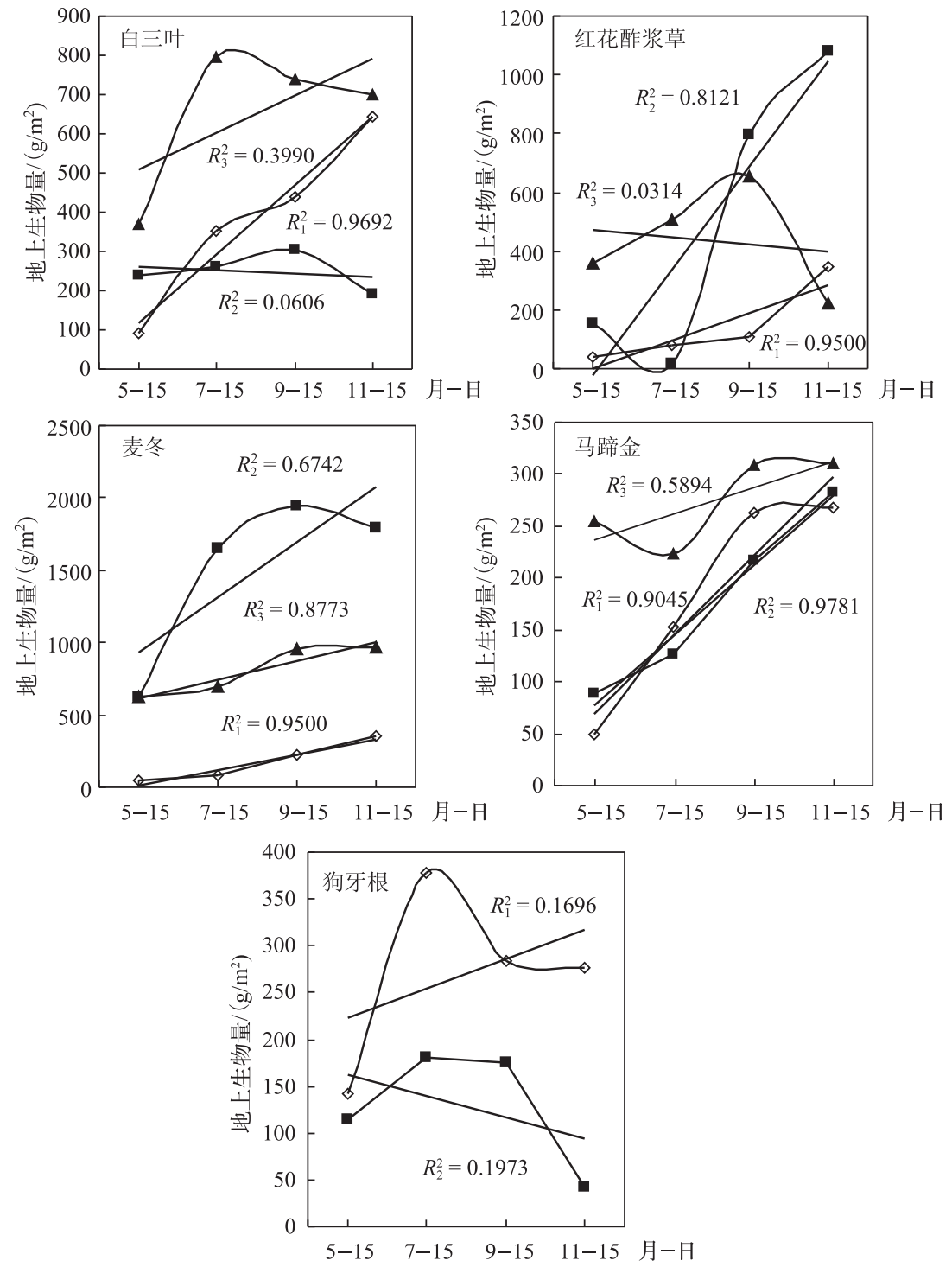

图 2 不同年份各草坪的生物量发展趋势( 图中直线为趋势线, $R_{1} 、 R_{2} 、 R_{3}$ 分别代表 2011 、

2013 和 2014 年趋势线; 曲线为生物量随月份的实际变化动态)

Fig.2 Biomass development trend of different kinds of lawn in different years

草坪的盖度并未随生长年限的增加而增大, 不同种类草坪盖度最大值出现的时期不同, 白三叶和狗牙 根一般在移栽的次年盖度较大,而红花酢浆草、麦冬和马蹄金则在移栽后的第 3 年盖度最好,这可能与植物 的生长分藮特征有关. 白三叶和狗牙根主要通过分蕉枝节上萌发的不定根进行匍匐式生长, 分蕉枝生长较 快, 前期生长的枝条被新生枝条覆盖后, 出现枯黄死亡现象, 尤其以狗牙根最为明显, 导致植被盖度随生长 时间的延长而降低. 移栽 3 年后, 盖度较高的草坪是马蹄金、麦冬和白三叶, 红花酢浆草盖度相对较低, 不同 生长阶段盖度差异较大,不稳定. 狗牙根最差,盖度基本为 0 (表 1 ).

\section{3 不同生长年限均一性与青绿期}

草坪的均一性是其密度与高度的综合体现, 白三叶移栽后的生长前期均一性相对较好, 草坪生长均匀。 随着生长时间的延长, 受各种因素的影响 (植物生长、病虫害等), 种群出现斑块, 均一性较差, 草坪质量趋于 
表 1 不同年份几种草坪的高度和盖度对比 *

Tab. 1 Contrast of height and coverage of different kinds of lawn in different years

\begin{tabular}{lcccc}
\hline 草坪种类 & 考察指标 & 2011 年 & 2013 年 & 2014 年 \\
\hline 白三叶 & 高度 $/ c m$ & $17.91 \pm 2.10^{\mathrm{a}}$ & $14.11 \pm 3.30^{\mathrm{b}}$ & $18.10 \pm 4.12^{\mathrm{a}}$ \\
& 盖度 $/ \%$ & $93.80 \pm 1.51^{\mathrm{a}}$ & $88.32 \pm 3.52^{\mathrm{b}}$ & $90.51 \pm 5.50^{\mathrm{a}}$ \\
红花酢浆草 & 高度 $/ \mathrm{cm}$ & $14.82 \pm 3.91^{\mathrm{a}}$ & $19.52 \pm 2.31^{\mathrm{b}}$ & $16.81 \pm 3.21^{\mathrm{ac}}$ \\
& 盖度 $/ \%$ & $58.81 \pm 2.32^{\mathrm{a}}$ & $76.74 \pm 13.52^{\mathrm{b}}$ & $70.00 \pm 11.80^{\mathrm{bc}}$ \\
麦冬 & 高度 $/ \mathrm{cm}$ & $13.80 \pm 2.91^{\mathrm{a}}$ & $42.51 \pm 2.90^{\mathrm{b}}$ & $38.51 \pm 3.22^{\mathrm{bc}}$ \\
& 盖度 $/ \%$ & $62.50 \pm 1.81^{\mathrm{a}}$ & $100.00 \pm 0^{\mathrm{b}}$ & $95.00 \pm 5.21^{\mathrm{bc}}$ \\
马蹄金 & 高度 $/ \mathrm{cm}$ & $6.52 \pm 2.21^{\mathrm{a}}$ & $9.90 \pm 0.31^{\mathrm{b}}$ & $10.51 \pm 2.31^{\mathrm{b}}$ \\
& 盖度 $/ \%$ & $95.60 \pm 2.51^{\mathrm{a}}$ & $100.00 \pm 0.00^{\mathrm{ab}}$ & $100.00 \pm 0^{\mathrm{ab}}$ \\
狗牙根 & 高度 $/ \mathrm{cm}$ & $13.33 \pm 4.51^{\mathrm{a}}$ & $12.81 \pm 0.81^{\mathrm{a}}$ & $0 \pm 0^{\mathrm{b}}$ \\
& 盖度 $/ \%$ & $97.52 \pm 2.31^{\mathrm{a}}$ & $90.00 \pm 1.70^{\mathrm{ab}}$ & $0 \pm 0^{\mathrm{c}}$ \\
\hline
\end{tabular}

* 同行不同小写字母表示各草坪不同年份间考察指标差异显著 $(P<0.05)$.

下降. 红花酢浆草与白三叶相似, 移栽后的前期, 植株密度相对均匀, 随着植株的不断萌发, 之间相互拥挤, 根部上移, 地下部分生长趋于增大, 而萌发新芽的球茎较少, 地上部分植株逐渐变稀, 分布不均匀. 麦冬草

表 2 不同年份草坪的均一性与青绿期

Tab. 2 Uniformity and green period of lawns in different years

\begin{tabular}{ccccc}
\hline 草坪种类 & 考察指标 & 2011 年 & 2013 年 & 2014 年 \\
\hline 白三叶 & 均一性 & 优 & 良 & 中 \\
& 青绿期/d & 250 & 255 & 260 \\
红花酢浆草 & 均一性 & 中 & 良 & 中 \\
& 青绿期/d & 230 & 235 & 240 \\
麦冬 & 均一性 & 中 & 优 & 良 \\
& 青绿期/d & 300 & 305 & 310 \\
马蹄金 & 均一性 & 优 & 优 & 优 \\
& 青绿期/d & 270 & 275 & 280 \\
狗牙根 & 均一性 & 优 & 良 & 劣 \\
& 青绿期/d & 210 & 215 & 0 \\
\hline
\end{tabular}

坪移栽后的前期植株分等枝还处于初期生长 阶段, 草坪密度与高度均不稳定, 均一性相对 较差, 随着新分榄枝的不断补充, 密度增大, 整 齐度也相对增加, 均一性较好. 移栽的第 4 年, 由于密度已趋于饱和, 而分藥还在缓慢进 行, 个别区域出现草丘, 因此, 草坪的整齐度出 现下降, 均一性也随之降低。马蹄金株型低 矮, 移栽后的前期其匍匐茎不断扩展, 形成均 匀的草坪, 由于其分策枝条较短, 因此, 随着生 长时间的延长, 草坪的密度与整齐度受分菜的 影响较小,均一性依然能够保持良好的状态. 狗牙根的分策枝条较长, 前期生长快, 随着生 长时间的延长, 枝条相互覆盖, 整齐度下降 (表 2).

林下几种草坪的青绿期不同, 狗牙根枯黄早, 返青晚, 青绿期较短. 红花酢浆草虽然枯黄晚, 但在夏季 高温时期出现休眠现象, 植株枯黄, 因此青绿期也较短. 白三叶和麦冬返青早, 枯黄较晚, 但白三叶在高温 时期会出现短期枯黄现象, 其青绿期受影响.马蹄金不能忍耐低温, 但太湖流域全年低于 $-5^{\circ} \mathrm{C}$ 的时期较少, 因此, 其青绿期仅次于麦冬. 总体而言, 麦冬青绿期最长, 其次是马蹄金, 再次是白三叶, 然后是红花酢浆 草, 青绿期最短的是狗牙根. 狗牙根与麦冬青绿期相差约 $90 \mathrm{~d}$.

由于年际间气候的差异, 同一种植物每年的青绿期也会发生一些变动, 受不同年份降雨和气温的影响, 2011 、2013 和 2014 年除消失的狗牙根外, 其他草坪青绿期随水热的增加略有增加.

\section{4 生长趋势评价}

主要考察草坪现实生长状况, 对草坪的生物量、盖度、高度、均一性和青绿期进行综合评定, 根据各指标 参数,按由高至低划分优、良、中、低、劣不同等级.

从生物量考量, 马蹄金不同年份间以及年内生物量均随生长时间呈增长趋势; 麦冬年内生物量呈增长 趋势, 但后期年度间出现下降; 白三叶不同年份间以及年内生物量均呈下降趋势, 但后期生物量呈现增长趋 势; 红花酢浆草和狗牙根生长后期年内与年份间生物量均呈现大幅度下降趋势, 尤其是狗牙根在移栽的后 期生长衰弱而消失. 鉴于此, 将马蹄金生物量指标评定为优, 然后依次是麦冬、白三叶、红花酢浆草和狗牙 
根, 等级逐渐降低.

从盖度考量, 草坪盖度随生长年份的变化特征与生物量相似, 因此, 盖度等级由高至低依次为马蹄金、 麦冬、白三叶、红花酢浆草、狗牙根. 从草坪生长的均一性考量, 由好至差依次为马蹄金、麦冬、白三叶、红花 酢浆草、狗牙根. 从青绿期考量, 保持绿色状态时间最长为麦冬, 然后依次为马蹄金、白三叶、红花酢浆草、狗 牙根.

综合以上各指标的评定结果 (表 3), 防护林下供试的 5 个草坪种类中, 综合指标表现最好的为马蹄金, 其次是麦冬,然后是白三叶,再次是红花酢浆草, 而狗牙根不能形成稳定的种群.

表 3 不同种类草坪考察指标的评定

Tab. 3 Review indicators evaluation of different kinds of lawn

\begin{tabular}{lccccc}
\hline \multirow{2}{*}{ 草坪种类 } & \multicolumn{5}{c}{ 考察指标 } \\
\cline { 2 - 5 } & 生物量 & 盖度 & 均一性 & 青绿期 & 综合结果 \\
\hline 白三叶 & 中 & 中 & 中 & 中 & 中 \\
红花酢浆草 & 低 & 低 & 低 & 低 & 低 \\
麦冬 & 良 & 良 & 良 & 优 & 良 \\
马蹄金 & 优 & 优 & 优 & 良 & 优 \\
狗牙根 & 劣 & 劣 & 劣 & 劣 & 劣 \\
\hline
\end{tabular}

\section{3 讨论}

太湖水污染中 $N$ 是主要因素, 主要由径流携带输人. 太湖防护林能够有效减少农业面源污染对太湖的 养分输人 ${ }^{[12]}$, 而林下草本植物群落对养分的循环具有重要影响. 杂草的世代更替产生大量枯落物 ${ }^{[3]}$, 枯枝 落叶是 $\mathrm{N}$ 流失的最主要存在形式和运输载体之一 ${ }^{[13-14]}$. 而枯落物分解是生态系统物质循环过程的重要环 节, 其分解过程和分解速率的变化将直接影响系统养分变化的进程 ${ }^{[5-19]}$. 虽然枯落物对径流具有一定的拦 截作用, 但仅限于降雨量较小的情况, 当连续降雨达到或超过饱和时, 其拦截作用就会丧失, 降雨全部转为 径流, 在一定的水流冲刷下水土与枯落物及其携带的养分会流失进人水体 ${ }^{[20-21]}$, 枯落物营养元素人湖量的 多少在很大程度上取决于降雨量与其持续时间, 降雨量大, 持续时间长, 形成的径流就大, 枯落物及其养分 随径流进人湖泊的风险也就高. 反之, 降雨量小, 持续时间短, 形成的径流小, 枯落物原地分解, 养分能够有 充裕的时间被土壤吸附和植物吸收.太湖流域属多雨地区, 3-9 月大部分时期降雨量达到中雨以上, 对湖 泊水体的养分输人具有极大的威胁.

植被转换能一定程度影响土壤 $\mathrm{N}$ 循环过程, 种类成分 (如不同功能型植物间的替代) 以及植物生长特性 的变化能够影响 $\mathrm{N}$ 循环过程的变化 ${ }^{[22]}$. 以多年生草坪替代杂草, 促进优势种向多年生植物演替, 形成稳定 的林草复合带, 可以有效减少系统枯落物的产生, 降低湖泊养分输人的风险. 此外, 草坪地面覆盖度高, 植 被与土壤的接触面大, 可减缓和降低雨滴降落时对土壤的冲击, 分散雨滴强度, 避免了雨水直接冲刷地面表 土,使大部分降雨为植被和土壤所涵养, 起到了防治水土流失、增强土体稳定的作用 ${ }^{[23-26]}$.

要形成稳定健康的林草复合植被带, 有效截留人湖养分, 首先草坪要能够适应林下的生长环境, 形成稳 定的具有健康发展趋势的种群. 其次, 草坪的生长特征要能够最大限度的截留养分, 不需要或减少人工 维护.

竞争植物的现实表现和潜在表现存在差异, 决定其在时间、空间延展过程中,适合度、优势度、存活率与 净繁殖率等特征的发展趋势, 使植物群落的组成、结构与功能发生改变 ${ }^{[27]}$.

研究的 5 种草坪均为多年生植物种类, 但具有不同的生物学特性, 这些特性在其进行时空延展过程中, 影响其在林下的发展趋势. 狗牙根喜光耐热 (可耐受 $43^{\circ} \mathrm{C}$ 高温), 当日均温度下降至 $6 \sim 9^{\circ} \mathrm{C}$ 时生长缓慢, 对 杂草的竞争力差, 虽然短期成坪较快, 但随着生长时间的延长, 不能形成稳定的种群被杂草取代. 麦冬喜温 暖、湿润环境, 抗旱、抗寒, 较耐阴, 生长期长, 休眠期短. 麦冬属中的许多种都适宜作林下地被植物, 不需要 特殊的管理, 在不同林分密度下其优势度、存活率与净繁殖率均较高. 马蹄金耐荫性较好, 可形成致密的草 
皮, 具有一定的侵占性, 与麦冬一样, 适应能力较强, 杂草竞争能力强. 白三叶再生力强, 生长快, 具有匍匐 茎, 能迅速覆盖地面, 但是白三叶喜光, 在林下生长受到一定限制. 红花酢浆草喜阴湿、温暖、湿润的环境, 不耐寒, 夏季有短期的休眠, 受水热的影响大, 生长不稳定. 林下种植具有良好发展趋势的多年生草坪, 使 一年生群落向多年生群落演替, 通过改变植物的现实组成结构, 促使其功能发生变化, 延长植物的养分吸收 过程,有效减少养分的对外输出, 提升太湖防护林的生态防护功能.

不同种类草坪上杂草的分布情况不相同, 反映了不同杂草在同一草坪群落环境下的适应能力以及其在 种内和种间的竞争能力不同, 同时也反映出不同种类草坪对入侵杂草的抵抗或抑制能力有差异 ${ }^{[28-29]}$. 蔡华 等利用麦冬的细胞学分析 ${ }^{[30]}$, 证明麦冬物种具有较强的抵御杂草人侵的特性. 本研究中麦冬在与杂草的生 长竞争中处于优势地位, 在疏林与密林中均能够形成稳定的种群。马蹄金属于浅根、阔叶、匍匐型草坪, 地 面盖度大, 其细根盘绕的根系特征, 可抑制杂草的生长, 也有利于径流人渗, 有效拦截径流. 有研究认为 ${ }^{[31]}$, 马蹄金在 $0^{\circ} \mathrm{C}$ 和 $5^{\circ} \mathrm{C}$ 时, 叶片内产生的自由基不足以使植物受到伤害, SOD 活性的增加可有效清除过多的自 由基而抑制过氧化作用, 从而减轻或避免冷害的发生, 只有在 $-5^{\circ} \mathrm{C}$ 以下其生长才受影响, 因此, 在太湖流域 低温对马蹄金生长的影响不大. 红花酢浆草与白三叶也具有较强的杂草竞争能力, 但是受水热的影响较 大, 尤其是红花酢浆草生长衰弱期与降雨同季, 不利于植物对径流养分的吸收与拦截. 狗牙根属于细叶匍 匐型草坪, 虽然其根茎能够较好的固土, 但杂草竞争力差 ${ }^{[32]}$, 随生长时间的延长, 趋于衰弱, 无法形成稳定的 种群而自然淘汰.从 5 种草坪的现实生长特征可以预测, 麦冬、马蹄金、白三叶和红花酢浆草在林下具有良 好的潜在发展趋势,综合其养分拦截功能考量,缓冲带林下较适宜的种类为麦冬和马蹄金.

\section{4 参考文献}

[ 1 ] 张维理, 武淑霞, 冀宏杰等. 中国农业面源污染形式估计及控制对策 I. 21 世纪初期中国农业面源污染的形式估 计. 中国农业科学, 2004, 37(7): 1008-1017.

[2] 李贵宝, 尹澄清, 周怀东. 中国“三湖” 的水环境问题和防治对策与管理. 水问题论坛, 2001, (3): 6-39.

[ 3] 刘长娥, 邹国燕, 付子轼等. 太湖湖滨带林草复合带草本植物枯落物量的变化特征. 环境科学研究, 2012, 25 (2): 153-158.

[ 4 ] 周华坤, 周兴民, 周 立等. 鹅线委陵菜的生长特征. 西北植物学报, 2002, 22(1): 9-17.

[ 5 ] 李冬杰, 杨培岭, 王 勇等. 土壤水分对草坪草蒸散及生长特性的影响. 草地学报, 2005, 13(4): 308-312.

[ 6 ] 初晓辉, 岳信龙, 任 健等. 水分胁迫下种冷季型草坪草抗早性比较研究. 草原与草坪, 2012, 32(4) : 15-19.

[ 7 ] Cook RE. Growth and development in clonal plant population. In: Jackson JBC, Buss LW, Cook RE eds. Population biology and evolution of clonal organisms. New Haven: Yale University Press, 1985 : 259-296.

[ 8 ] Dong M, Kroon H. Plasticities in morphology and biomass allocation in Cyondon dactylon, a grass species forming stolons and rhizomes. Oikos, 1994, 70: 99-106.

[9] 张永亮, 张 浩. 行距与氮肥对荫草分蕃和产量的影响. 中国草地学报, 2013, 35(2): 43-47.

[10] Matthew C, Assuero SG, Black CK et al. Tiller dynamics of grazed swards. CAB International Grassland Ecophysiology and Grazing Ecology, 2000: 127-150.

[11] 王艳红, 王 珂, 邢 福. 匍匐茎草本植物形态可塑性、整合作用与受食行为研究进展. 生态学杂志, 2005, 4 (1) : 70-74.

[12] 孙 慧, 张建锋, 单奇华等. 宜兴太湖防护林对农业面源污染的减源增汇作用浅析. 湖泊科学, 2015, 27(2): 227-233. DOI 10. 18307/2015. 0205.

[13] De Deyn GB, Quirk H, Bardgett RD. Plant species richness, identity and productivity differentially influence key groups of microbes in grassland soils of contrasting fertility. Biology Letters, 2011, 7: 75-78.

[14] Eviner VT, Chapin FS, Vaughn CE. Seasonal variations in plant species effects on soil N and P dynamics. Ecology, 2006, 87: 974-986.

[15] Hassanin AS, Labib TM, Gaber EI. Effect of vegetation cover and land slope on runoff and soil losses from the watersheds of Burundi. Agricultural Ecosystem and Environment, 1993, 43: 303-308.

[16] Duchemin M, Hogue R. Reduction in agricultural non-point source pollution in the first year following establishment of an integrated grass/tree filter strip system in southern Quebec (Canada). Agriculture, Ecosystems and Environment, 2009, 
131 : 85-97.

[17] Jordan C, Smith RV. Factors affecting leaching of nutrients from an intensively managed grassland in County Antrim, Northern Ireland. Journal of Environmental Management, 1985, 20: 1-15.

［18］彭少麟, 刘 强. 森林调落物动态及其对全球变暖的响应. 生态学报, 2002, 22(9): 1534-1544.

[19] Tuomi M, Thum T, Järvinen H et al. Leaf litter decomposition-estimates of global variability based on Yasso 07 model. Ecological Modelling, 2009, 220: 3362-3371.

[20] Park A, Friesen P, Serrud ASA. Comparative water fluxes through leaf litter of tropical plantation trees and the invasive grass Saccharum spontaneum in the Republic of Panama. Journal of Hydrology, 2010, 383: 167-178.

[21] Vadas PA, Haggard BE, Gburek WJ. Predicting dissolved phosphorus in runoff from manured field plots. Journal of Environmental Quality, 2005, 34(4) : 1347-1353.

[22] Picasso VD, Brummer EC, Liebman M et al. Crop species diversity affects productivity and weed suppression in perennial poly cultures under two management strategies. Crop Science, 2008, 48: 331-342.

[23] Sehoonover JE, Williard KWJ, Zaczek JJ. Nutrient attenuation in agricultural surface run off by riparian buffer zones in southern Illinois, USA. Agroforestry Systems, 2005, 64(2) : 169-180.

[24] Lee KH, Isenhart TM, Schultz RC. Sediment and nutrient removal in an established multi-species riparian buffer. Journal of Soil and Water Conservation, 2003, 58(1): 1-8.

[25] 王秋光, 李永峰, 李春华等. 林草复合植被缓冲带结构功能及净化机理研究综述. 中国水土保持, 2013, 6: $39-42$.

[26] 秦树高, 吴 斌, 张宇清. 林草复合系统地上部分种间互作关系研究进展. 生态学报, 2010, 30(13): 3616-3627.

[27] 任丽丽, 刘金平. 酢浆草侵人量对马蹄金相对竞争力和幼坪性状的影响. 西南农业学报, 2013,26(2)：737-741.

[28] 谭永饮, 张国安, 郭尔祥. 草坪杂草生态位研究. 生态学报, 2004, 24(6): 1300-1305.

[29] Eric W, Scabloom, Stanley W et al. Invasion, competitive dominance and resource use by exotic and native California grassland Species. Proceedings of the National Academy of Sciences of the USA (PNAS), 2003, 100(23) : 13384-13389.

[30] 蔡 华, 夏海武, 王荣富. 麦冬草坪群落中杂草的分布及细胞学研究. 草业科学, 2007,16(4): 87-92.

[31］张文惠，呼天明. 低温胁迫对马蹄金抗性生理生化指标的影响.吉林农业大学学报, 2002, 24(5): 39-41.

[32] 胡 铁, 张 彪, 张 平等. 湘北地区狗牙根草坪杂草的种类、分布及其危害程度的评价. 杂草科学, 2005, 4: 16-18. 